\title{
THE EU MEMBERSHIP OF A LOOSELY CENTRALISED 'FEDERAL' CYPRUS: A STRATEGY OF COOPERATION AND CONFLICT-MITIGATION*
}

\author{
H. TARIK OĞUZLU
}

\begin{abstract}
As the time approaches for the European Union to decide on the membership of the Island, the current ambiguous approach of the EU does not seem to offer to parties credible incentives to come to settlement. Instead, performances of the all interested parties so far have demonstrated that the 'cooperation-promoting, conflict-mitigating' character of the EU's accession process has not yielded the expected result. This paper argues that if the EU's current Cyprus policy leads to an early membership of the Greek Cypriot part of the Island as representing the whole Island, the risks to security and stability in the region would escalate. It further suggests that the EU needs to reconsider its current approach and needs to advocate the EU membership of a loosely centralised federal Cyprus.
\end{abstract}

\section{KEY WORDS}

Cyprus; European, Union; Cyprus Problem; Federalizm.

\footnotetext{
* Editor's Note: This article was completed and submitted in May 2002, long before latest Denktas-Klerides talks and 'Annan Plan'.
} 


\section{Introduction}

Though the EU's involvement in the Cyprus dispute has the potential to help the interested parties to reach a reconciliation, this paper argues that unless the current approach of the EU is changed, the ongoing accession process between the EU and the Greek Cypriots, on behalf of the whole Island, will lead to no where but further perpetuation of the conflict.

As the time for the EU to decide over the accession of the Island approaches, it seems that the EU will find itself in a very difficult situation mainly for two reasons. First, the EU's ambiguous attitude towards the optimum way of membership of the Island seems not to have encouraged the Turkish and Greek Cypriots to sincerely accommodate their diverging negotiation positions. It is not clear yet whether the EU would agree to the membership of the Greek Cypriots as representing the whole Island or it would welcome a new partnership state that may come to surface should the parties agree on its details.

The second reason pertains to the risks, which the EU might face with, if Greece and Turkey prove adamant in carrying out their threats/warnings. While the Greek threat to veto the next enlargement process of the EU to the Central and Eastern European Countries (CEECs) if the EU does not let the Greek Cypriots in, due to the continuation of the stalemate on the Island, may endanger the whole enlargement process, the Turkish threat to intensify the integration process (while keeping the door to annexation open) with the Turkish Republic of Northern Cyprus (TRNC) in case the EU admits the Greek Cypriots into membership as representing the whole island may prove a destabilising factor in regional security considerations. The danger with the realisation of the Turkish threat lies in the fact that such a development in the region might pit Turkey and the EU against each other. The probability of the EU and Turkey facing each other as contenders will further increase, should the EU does not improve the quality of Turkey's accession process, for example by agreeing to the start of the accession talks, due to the continuation of the stalemate on the Island.

That said, it will be contended in this paper that if the EU wants to avoid of these crises and to make its involvement more effective and 
promising, it had better make it clear that it regards the EU membership of a loosely centralised, single-sovereign, bi-zonal, and bicommunal federal Cyprus as the only feasible and legitimate solution. Only through this way the EU would be able to demonstrate that it values the resolution of the Cyprus problem more than its conjectural interests in the enlargement process. Supporting the EU membership of a loosely centralised federal solution would help the EU exert equal pressure on both communities of the Island, as well as Turkey and Greece. Neither the Greek Cypriots would dare to insist on the tightlycentralised federal structure risking the permanent division of the Island, nor the Turkish Cypriots would dare to ask for the confirmation of two sovereign states risking the perennial evaporation of Turkey's hope for the EU membership.

Against this background, the next part of the article will explore the possibilities whether one could portray the projection of the EU's 'security community' identity through the accession processes as peace and cooperation promoting mechanism. Afterwards, the attention will turn to the EU's Cyprus policy to date. The part that follows will shortly discuss the main reasons why the involvement of the EU so far has not produced any tangible benefits for the parties concerned. Following this, an attempt will be made at projecting the EU membership of a loosely centralised federal Cyprus as the most practical strategy for all the interested parties to ward off possible dangers of the EU membership of a divided Island. The conclusion will recap the main points of the paper.

\section{The Accession Process as Promoting the EU's 'Security Community' Identity}

It is conventionally accepted among scholars that living within the institutional environment of the EU contributes to peaceful and cooperative relations among the members states. ${ }^{1}$ Due to the 'security community' character of the EU's internal environment and the highly interdependent nature of the socio-economic transactions among the EU citizens, member states do not resort to threat and use of force in

\footnotetext{
*See Martin Smith and Graham Timmins, 'The EU, NATO and the Extension of Institutional Order in Europe', WorldAffairs, Vol. 163, No.2, 2000, pp. 80-90.
} 
their dealings with each other. EU member states would be expected to sort out their frictions, either of interstate or intra-state nature, through peaceful ways of conflict resolution including negotiations, bargaining, consultation, and arbitration.

It is further assumed that the process of projection of the EU's identity to the peripheries of the continent would contribute to the stabilisation of interstate and intra-state relations there. Instead of providing hard security to the countries, which are associated with the EU through accession processes, the EU is conceptualised as an institution that offers to would-be members soft security guarantees by requiring them to adjust the letter and spirit of their domestic political and social structures to the institutionalised norms of the EU's environment. $^{2}$ Being a 'power of attraction', the most important means that the EU wields in this process is its capability to implement a policy of conditionality backed by a formal process of screening. It isv hoped that the candidate states would avoid of being seen as belligerent and intransigent when trying to sort out their territorial problems with their neighbours because they would not dare to risk losing the benefits of EU membership should they are seen as unfit for the EU environment.

Construed as such, the most vital conditions for the internalisation of the EU norms by the candidate countries would be the followings: First, the EU needs to develop credible packages of carrots and sticks. Otherwise, those states, which aspire to join the EU, would be left without strong incentives to alter their mentalities. ${ }^{3}$ Formulation by the EU of credible rewards and punishments would mean that the EU desires the membership of any candidate country on the ground that the inclusion of that particular country would contribute to the international representational identity of the EU. Only in such a case, the EU would act as an agent of socialisation in

\footnotetext{
${ }^{2}$ Emanual Adler, 'Imagined (Security) Communities: Cognitive Regions in International Relations', Millennium, Vol. 26, No. 2, 1997, pp. 249-77.

${ }^{3}$ Thomas Diez, The Imposition of Governance: Transforming Foreign Policy through EU Enlargement, Copenhagen Peace Research Institute, August 2000, at: [http://www.copri.dk/publicationsAVPAW\%202000/21-2000.doc].
} 
familiarising candidate states with the requirements of the membership. ${ }^{4}$

Secondly, there must be a consensus among the domestic interest groups, be it political, economic, social, religious and cultural kind, within candidate countries that the internalization of the EU identity would enhance the security and prosperity of the nation. If, and only if, candidate countries were serious and adamant to attain the EU membership, then they would be eager to harmonise their internal and external identities with those of the European Union. ${ }^{5}$

The most visible signs of a 'cooperation-promoting, conflictmitigating' EU accession process in candidate countries would take place as those states gradually adopt pro-EU discourses. While the 'desecuritasing discourse' would, on the one hand, symbolise the willingness of the domestic elites in candidate countries to cease depicting their neighbours as existential threats, the 'integration discourse' would, on the other hand, supersede the 'sovereignty discourse' as such that domestic actors would convincingly argue that the security of their countries would lie in the integration with the EU. ${ }^{6}$

Thought of this way, it would be rational to argue that the involvement of the EU in the Cyprus dispute will usher in a more stable and cooperative atmosphere in and around the Island as both Turkey and the Greek Cypriot Administration seem to be conditioned by their accession processes with the EU. However, the danger is that the EU's accession process might quite contrary increase the risks to security and stability in a region, if the logic of whole accession process is built on the following conditions. First, any candidate

${ }^{4}$ Frank Schimmelfennig, 'International Socialisation in the New Europe: Rational Action in an Institutional Environment', European Journal of International Affairs, - Vol. 6, No. 1, 2000, pp. 109-39.

${ }^{5}$ Ibid. The point is that changes in foreign policy bahaviours of the candidate countries would be more solid and long-lasting had those changes been brought about by a transformation in the identities of those states, rather than the adoptation of their preferences to the conjectural realities, hi the second case, deviations from the 'EU-typical foreign policy behaviours' would be likely in case states found it detrimental to act so.

${ }^{6}$ Grazina Miniotaite, The Security Policy of Lithuania and the 'Integration Dilemma', The Copenhagen Peace Research Institue, May 2000, at: [http://www.copri.dk/publicationsAVPAVP\%202000/5-2000.doc]. 
country acts with an instrumental logic in an effort to make use of the future benefits of the EU membership in order to materialise its political and security interests vis-à-vis its enemies or rivals. ${ }^{7}$ Second, the EU pretends that it is willing to offer membership to any candidate country but falls short of developing credible incentives.

In the light of these theoretical insights, the case of EU's involvement in the Cyprus dispute seems to provide a good opportunity to assess whether and how the EU accession process would contribute to peace and stability in conflict-riven areas.

\section{The Basics of EU's Attitude towards Cyprus}

The current Cyprus policy of the EU can be summarised in three conflicting sentences. First, the EU would not regard the resolution of the political deadlock on the island as a precondition before the mebership of the Island. ${ }^{8}$ Second the EU will take all relavant factors into account when deciding whether or not to admit the Island into membership. ${ }^{9}$ Third, the EU would most likely approve of any political settlement between the Turkish and Greek Cypriot communities and would not create problems during the implementation process of the EU's internal regulations in each part of the Island. ${ }^{10}$ These conflicting sentences were formulated to send different messages to all interested parties to the conflict. While the first statement seems to have sympathised with the Greek Cypriots' view, the second adressed to Turkey and the last one aimed at encouraging the Turkish Cypriots to show more commitment to the EU membership of the Island. However balanced such a tree-dimensional EU Cyprus policy might appear, the

${ }^{7}$ Diez, The Imposition ofGovernmence,

${ }^{8}$ This is implied in the Article 9-b of the EU's Helsinki Summit Conclusions: '...If no settlement has been reached by the completion of accession negotiations, the Council's decision on accession will be made without the above being a precondition... '.See [http://europa.eu.int/council/oiTCconclu/dec99/dec99_en.htm].

9 '...In this the Council will take account of all relevant factors.' This is the second paragraph of the same article.

${ }^{10}$ European Commission Pres Release: Speech/97/272, December 03, 1997 EU: Van den Brook Speech on 'Reconcilation in Cyprus'. 
danger is that the EU has given its moral support to the first approach rather than the last two. $\bullet^{\prime}$

When the European Commission announced its opinion in July 1993 on the membership application of the Greek Cypriots, it recommended that the accession process should follow the resolution of the dispute. ${ }^{12}$ Otherwise, the EU would have to encounter serious problems, for instance the importation of the Turkish-Greek disaggreement over the Island to the EU. However, the EU soon reversed its position and decided to include Cyprus within the next group of countries to be admitted to the EU. This about-turn in the EU's position became clear for the first time in the EU's Corfu summit meeting in June 1994 and later was confirmed in the Essen summit in December of the same year. ${ }^{13}$ On 6 March 1995, on the sidelines of the signing of the Customs Union Treaty between the EU and Turkey, the EU's General Affairs Council added a new dimension to the declared Cyprus policy of the EU by establishing a link between Turkey's relations with the EU and and the EU membership of Cyprus. The deal was that Greece would lift its veto over Turkey's Customs Union with the EU in return for the EU's agreement to start the accession talks with the Greek Cypriots on behalf of the whole Island six months after the end of the Intergovernmental Conference to be held in Amsterdam.

Then came the EU's Agenda 2000 where the EU for the first time announced that an 'a priori' resolution of the Cyprus problem would not constitute a precondition for the membership of the Island in the European Union. ${ }^{14}$ With the EU's 1997 Luxembourg decisions, the EU decided to include Cyprus within the first track countries, with which the accession talks would start in March 1998, while denying

${ }^{11}$ Cyprus: Republic of Cyprus-Gunter Verhungen refers to the Cyprus at the Plenary Session of Europe, RDATE: 14/03/2002, Spanish Foreign Minister Mr. Josep Pique has stated that the resolution of the Cyprus conflict is not a precondition for the membership of the island in the EU.

${ }^{12}$ For the text of the opinion of the European Commission on the application of the Greek Cypriots for the EU membership, see: [http://europa.eu.int/comm/enlargement/cyprus/index.htm].

${ }^{13}$ One can reach the clauses of the EU's Corfu and Essen Summits on Cyprus at: [http://europa.eu.int/comm/enlargement/cyprus/index.htm].

${ }^{14}$ [http://europa.eu.int/comm/enlargement/index.htm]. 
Turkey of the formal candidateship status. ${ }^{15}$ The EU's 1999 Helsinki Summit decisions formally confirmed that the resolution of the Cyprus problem would not be considered as a precondition for the membership of the Island in the EU. The Union also resolved to take all the relevant factors into account when the time comes to decide over the accession of the Island to the EU. The same summit also granted candidate status to Turkey while making the solution of Turkey's disputes with Greece as one of the preconditions for the start of the accession talks with Turkey. ${ }^{16}$ The link between Turkey's and Cyprus' EU memberships was once again confirmed in the Accession Partnership document of December 2000, which the EU prepered as Turkey's road map for the EU membership. Turkey was required by the EU, as part of the shortterm requirements, to constructively encourage the United Nations' attempts at finding a solution to the Cyprus dispute. Thus Turkey was implicitly asked to exert pressure on the Turkish Cypriots to show a more concilatory stance vis-a-vis the Greek Cypriots. ${ }^{1}$

In contrast to hopes that the EU's involvement in the Cyprus dispute would lead the parties on the Island to accelerate the solution process, what happened was the gradual estrangement of the parties from each other. In response to the EU's Luxembourg decisions, Turkey and Turkish Cypriots have decided to give further momentum to their efforts for further integration. The logic was that the more the EU integrates with the Greek Cypriots, the more Turkey integrates with the Turkish Cypriots. ${ }^{18}$ Besides, there has taken place a gradual hardening in the official position of Turkey as for the appropriate solution of the dispute. The years-long federal solution has been replaced by a confederal approach. Turkey did not hesitate to give its

\footnotetext{
${ }^{15}$ [http://ue.eu.int/Newsroom/related. asp?max=1 \&bid=76\&grp=1049\&lang=1 ] .

${ }^{16}$ [http://ue.eu.int/Newsroom/related. asp?max=1 \&bid=76\&grp=2186\&lang=1 ].

${ }^{17}$ For Turkish Accession Partnership document, [http://europa.eu.int/comm/enlargement/turkey/pdf/ap_turk_en.pdf ].

${ }^{18}$ William Park, 'Turkey's European Union Candidacy: From Luxembourg to Helsinki to Ankara', Mediteranean Politics, Vol. 5, No. 3, 2000, pp. 31-53. See also Hilseyin Bağci, 'Turkish Reactions to the EU Approach,' in Susanne BaierAllen (ed.) Looking into the Future of Cyprus-EU Relations, Baden-Baden, Nomos Verlag, 1999, pp. 39-50.
} 
backing to President Denktaș's 'Confederal Cyprus' solution whose details were made public in late August $1998 .{ }^{19}$

The so far performance of the EU's involvement in the Cyprus dispute has demonstrated three things. First, the cooler and less intensive Turkey's relations with the EU are, the less conducive an environment exists to an inter-communal negotiation process and the less conciliatory the Turkish Cypriots become towards the Greek Cypriots. Second, if the EU continues to proceed with the accession talks only with the Greek Cypriots as representing the whole Island, then prospects for resolution will be dim with the political environment on the Island turning out to be more 'securitised'. Thirds, the Turkish political/military elites have come to the conclusion that the EU acts towards Turkey from an instrumental perspective. To them, it is not a mere coincidence that the EU has taken three fundamental decisions in Helsinki at the same time. While the EU offered to Turkey candidacy status on the one hand, it took historical decisions in the area of Common Foreign and Security Policy by resolving to construct a European Army of 60.000 troops by the end of 2003 on the other. In parallel to Turkey's candidacy, the EU also made it clear that the resolution of the political stalemate in Cyprus would not constitute a precondition before the membership of the Island in the EU. When these three significant decisions of the EU combined, the Turkish elites concurred that the main motivation behind the EU's decision to grant Turkey the candidacy status was the EU's attempt at forestalling any Turkish action that might obstruct these processes. When this is the case, the willingness of Turkey to encourage the Turkish Cypriots to come to an accommodation with the Greek Cypriots sank to the bottom.

\section{Wrong Assumptions Lead to Failure}

It is now the time to pay a closer attention to the underlying assumptions, which the EU circles believed, that would have generated catalytic effects on the Island. It is one of the arguments of this essay that unless they are fundamentally reversed, no breakthrough would be

\footnotetext{
${ }^{19}$ Denktaş's Confederation proposal can be found at: [http://www.mfa.gov.tr/grupa/ad/add/305.htm].
} 
in the offing. The first assumption was that the conflicting parties conflict would regard the involvement of the EU as impartial. However, this proved to be wrong given that Greece has been an EU member since 1981 and succeeded in exploiting the EU mechanisms in pursuing its interests vis-à-vis Turkey. It would be highly unconvincing to argue that the EU would have adopted its current Cyprus policy even if Greece had not been an EU member. ${ }^{20}$

The second flawed assumption was that the economic benefits of the EU membership would be enough to buy the consent of the Turkish Cypriots into the EU membership of the Island. Both the flow of money from Brussels within the framework of the EU's regional and structural funds and the ending of the economic embargo have been assumed to fundamentally alter the preferences of the Turkish Cypriots. $^{21}$ Both assumptions proved wrong, since the Turkish Cypriots, let alone softening their approaches, have become more antiEU as the accession process continued. The incentives on the part of the Turkish Cypriots to seek a resolution of the conflict through the accession process with the EU lessened, since the accession process has been viewed as biased in favour of the Greek Cypriots. For them the continuation of Turkey's security guarantee and the presence of the Turkish troops on the Island, rather than the co-habitation with the Greek Cypriots within the EU, have proved to be more vital in terms of their security. It is not the economic well-being but physical and societal security that matter more for the Turkish Cypriots. ${ }^{22}$

\footnotetext{
${ }^{20}$ Though the mainstream Turkish view puts the blame for the negative Turkish-EU relations on Greece, some authors argue that Greece has been only the scapegoat. For example Uğur claims that Greece does not possess the means to affect the fundamental course of EU-Turkey relations and the main responsibility for the negative spirals in EU-Turkey relations rest with the parties themselves. Because they do not fulfill their obligations arising out of the integration process, they find an exit in Greece's taken for granted anti-Turkey mood. Mehmet Uğur, The European Union and Turkey: An Anchor/Credibility Dilemma, Aldershot, Ashgate, 1999), pp. 194-195.

${ }^{21}$ Susanne Baier-Allen, 'Assessing the Impact of the EU Accession Process on the Cyprus Conflict: Incentive for Conflict Resolution?' in Baier-Allen (ed.), Looking into the Future of Cyprus-EURelations, pp. 171-186.

${ }^{22}$ Thomas Diez, Last Exit to Paradise? The EU, The Cyprus Conflict, and the Problematic 'Catalytic Effect', Copenhagen Peace Research Institute, June 2000; See also Necati Mtinir Ertekiin, 'The Turkish Cypriot Outlook', in Clement H. Dodd (ed.), Cyprus: The Needfor New Perspectives, London, The Eothen Press, 1999, pp. 97-113.
} 
The third assumption was that not only the Turkish Cypriots but also the Greek Cypriots would soften their negotiating positions. The EU membership of the Island would be a supporting reason for the Greek Cypriots to feel themselves more secure, therefore there seemed to be nothing wrong for them to give the Turkish Cypriots something more than what they had offered so far. However, since 1995, the Greek Cypriots behaved in such a way as to refute these expectations by hardening their negotiation positions. Neither the inter-communal talks in the second half of 1997, nor the negotiations between December 1999 and September 2000, have been indicative of any softening in the Greek Cypriot policies. This should not have been difficult to capture given that the real motivations behind the Greek Cypriots' application for the EU membership were political and aimed at having the EU legitimise the Greek Cypriot claims. ${ }^{23}$ When the EU made it clear that the resolution of the conflict would not be a precondition for the membership of the Greek Cypriots to the EU as representing the whole Island, the incentives on the part of them to negotiate a new deal with the Turkish Cypriots decreased. Why would the Greek Cypriots agree to share their internationally recognised sovereignty over the Island with the Turkish Cypriots under a new political framework where both communities would be considered as politically equal?

The fourth flawed assumption held that Turkey would value its interests in the EU membership more than its other interests. The expectation was that the more the EU upgrades the level of its relationship with Turkey, the more pressure Turkey would exert on the Turkish Cypriots to come to terms with the Greek Cypriots. However, this also proved wrong, for Turkey did not only dare to freeze its political relations with the EU in the aftermath of the Luxembourg rebuke, but also seemed to have reverted back from its years-long federation policy by backing the confederal arguments of the President DenktasofTRNC.

\footnotetext{
${ }^{23}$ Neill Nugent, 'EU Enlargement and the 'Cyprus Problem", Journal of Common Market Studies, Vol. 38, No. 1, 2000, pp. 131-150. See also Kevin Featherstone, 'Cyprus and the Onset of Europeanisation: Strategic Usage, Structural Transformation and Institutional Adoptation', South European Society and Politics, Vol. 5, No. 2, 2000, pp. 141-162.
} 
In analysing Turkey's policies vis-à-vis Cyprus, one needs to point out that its interests in the Island have been well-established and independent of the dynamics of its relations with the EU. Turkey thinks that by keeping its strategic control over the Island (at least the northern part of it), it both maintains the strategic balance with Greece at acceptable levels and helps nurture the impression that it can serve the interests of the western international community in the Eastern Mediterranean region better than the Greeks/Greek Cypriots. For Turkey the matter is not either the EU or Cyprus. It wants to become an EU member, upholding the European interests and contributing to security and peace in the region. What makes the Turkish political and military elite feel worried is their anxiety over the real intentions of the EU. Their perception is that if the EU were seriously committed to Turkey's membership in the EU, why it was elevating the prior resolution of the Cyprus conflict to one of the fundamental preconditions for Turkey's entry in to "the club". After all, when Turkey became an EU member, all border restrictions would be eliminated and the region would turn out to be a zone of peace and cooperation in the presence of the joint EU memberships of Turkey, Greece and Cyprus. ${ }^{24}$ If the changing parameters of the international system allow a greater role to the EU in the Eastern Mediterranean and the Middle East; if the EU decides to pursue its interests in these regions through Greeks/Greek Cypriots; and if the EU does not envision Turkey's membership soon, it is highly likely that Turkey would continue to view the developments over the Island from a strategically oriented realpolitik perspective.

The final flawed assumption was based on the idea that an EUinduced negotiation process would encourage the communities on the Island to pursue a settlement along the well-established UN designed frameworks. This was wrong for a number of reasons. For example while the Turkish and Greek Cypriots have been treated as two politically equal communities during the UN-designed inter-communal talks, the EU's accession process seems to have reversed this status by according the Greek Cypriots legitimacy to speak on behalf of the two

\footnotetext{
${ }^{24}$ This is one of the major arguments of the Euro-sceptics in Turkey. See Erol Manisah, Avrupa Qikmazi Istanbul, Otopsi Yayinlan, 2001.
} 
communities. $^{25}$ While the UN framework envisages separate public referendums for the final settlement to come into force, the EU seems to have been ready to recognise the EU membership of the Greek Cypriots on behalf of the two communities even before a mutually acceptable political settlement is reached. The involvement of the EU might also seem to be in conflict with the fundamental parameters of the UN-designed solution framework. Neither the principle of bizonality, which allows for the Turkish Cypriots to make laws in their autonomous region, nor the gradual implementation of the three fundamental rights of movement, settlement and buying property seem to operate well with the internal regulations of the European Union, unless the EU made it clear and straightforward that either temporary or permanent opt-outs from these regulations would be guaranteed. Besides, the EU membership of the Greek Cypriots as representing the whole Island would make the presence of the United Nations Force in Cyprus contestable. Under what conditions would such a force continue to operate within the borders of the European Union? Would it patrol the borders of an EU-member state or help the two communities of the Island buy time for intensive inter-communal talks?

\section{The EU Membership of a Divided Cyprus: Good or Bad?}

In order to argue for the merits of a loosely centralised federal arrangement on the Island, one needs to underline the probable consequences of the most likely scenario in the months ahead, e.g., the EU membership of the Greek Cypriots as representing the whole Island. In such a case the Greek Cypriots would permanently loose their hopes of a unified Cyprus where it could be possible for them to enjoy one day all of the three fundamental rights throughout the Island. Besides, their incentive for any further round of inter-communal talks would go down, for given their EU membership they would feel less motivated to accommodate the claims of the Turkish Cypriots as part of a final deal. They would also have to increase their military spending in the face of escalated risks in the region. Their economic performance would be negatively affected by the escalation of the crisis

\footnotetext{
${ }^{25}$ Yannis A. Stivachtis, 'The Enlargement of the European Union: The Case of Cyprus', paper presented to International Studies Association, $41^{\text {st }}$ Annual Convention, Los Angeles, CA., March 2000.
} 
environment on the Island, since foreign investors would not want to come to the Island to invest their capitals. Besides, sharp reductions in the profits of the lucrative tourism sector would be likely. It is for certain that an EU member divided Cyprus would constitute a major source of friction in EU-Turkey relations due to its determined antiTurkish attitude. $^{26}$

The Turkish Cypriots would not be immune from the negative consequences of the EU membership of a divided Cyprus either. First of all, their dependency on Turkey would increase tremendously in many policy areas. The economic benefits of the EU membership would be foregone. This situation would level a serious blow to their communal identity and the years-long claim that they possess an independent and sovereign state. $^{27}$ In parallel to the increased integration with Turkey, more settlers may come from Turkey and the Turkish Cypriots might find themselves as the minority community in their territories. Besides, the increased economic dependency on Turkey would not relieve them of their current economic problems. Neither the economic embargo, put on them by the Greek Cypriots and endorsed by the European Union, would be lifted, nor the deteriorating economic performance of Turkey would be able to bail them out on future occasions of financial crisis.

Turkey would also be affected by the membership of a divided Cyprus in the EU negatively. First of all, the addition of the Greek Cypriots to the anti-Turkish block within the EU would lessen Turkey's chances for future EU membership. Second, the EU might not start the accession talks with Turkey on the pretext that the latter has not worked enough to encourage the Turkish Cypriots to come to an agreement. If the accession talks with the EU do not take off the ground in the next two to three years, particularly due to the reason for the continuation of the stalemate on the Island, Turkey's relations with the EU would be seriously severed. If Turkey proceeds to annex the TRNC to the mainland, then Turkey's hope to join the EU will sink to

\footnotetext{
${ }^{26}$ Henri J. Barkey and Philip H. Gordon, ' Cyprus: The Predictable Crisis', The National Interest, Issue 66, Winter 2001-2002, pp. 83-94.

${ }^{27}$ Ibid.
} 
the bottom. ${ }^{28}$ In Turkey the pace of EU-induced transformation process would slow down. In parallel to heightened tensions in the Island, Turkey might find itself spending more on armament, thus forsaking investments on more lucrative fields.

Moreover, the anti-EU forces in Turkey gain political power against those who see the future of the country in closer integration with the EU. Although, Turkey so far have set the course for its future direction towards the EU, devoid of the membership prospects in the EU, it might find itself in investing too much capital and energy on discussions of identity. It is sure that this process would be costly and divert attention of the country away from further modernization. Turkey would also have to channel huge amount of financial resources to the Turkish Cypriots to buttress their position on the Island.

The most important consequence of this scenario would be seen on the ongoing negotiation process between Greece and Turkey. All the gains of the last three years in the bilateral relations might be squandered. If the atmosphere soured in the Aegean Sea, risks to regional and continental security might abound with Greece and Turkey finding themselves on the opposite sites. One additional disadvantage of the non-membership of the Island in the EU would be that Turkish would not be registered as an official language spoken within the EU zone. However, if registered, the use of Turkish language might lead to the evaporation of one of the psychological barriers before Turkey's membership in the EU. ${ }^{29}$

Greece would also feel the negative consequences of the crisis situation on the Island. The pro-EU-integrationist Smitis government in Athens might be exposed to harsh criticism at home as such that Europeanising the Turco-Greek relations did not yield to satisfactory outcomes for Greece. Critics might accuse the PASOK government of its conciliatory attitude toward Turkey on the ground that neither the bilateral negotiation process since the late 1999, nor the transformation

\footnotetext{
${ }^{28}$ William Wallace, 'Reconciliation in Cyprus: The Window of Opportunity', Mediterranean Program Report in the Framework of the Programme on Support Activities in Connection with Turkey's EU Candidacy and Its Role As a Key Partner of the EU, Robert Schuman Centre, European University Institute, MP.RM/2002.

${ }^{29}$ Barkey and Gordon, 'Cyprus: The Predictable Crisis'.
} 
of the dynamics of the Turkish-Greek relations into EU-Turkish relations did help Greece see the accession of Cyprus to the EU undivided in favour of the Greek Cypriots. Greece's defence expenditures would increase in order to keep pace with Turkey. ${ }^{30} \mathrm{~A}$ Greece, which would have to live next to a Turkey that would have further estranged from the European Union, would in no way feel itself so secure as to channel its energy and resources to the completion of its Europeanization program. For Greece, to be able to join the first tier of EU member countries and to enjoy the peace dividend of the post-Cold War era, it seems to be a must that Turkey is attached to the EU with a strong prospect for membership.

The European Union as an institution or the EU member states would also be negatively affected from the membership of a divided Cyprus. In addition to the escalation of risks to the security and stability in the region, the EU would found itself having a member state whose borders are patrolled by the UN forces. Imagine the negative impact of this on the EU's institutional identity. In case the divided Island became an EU member, it would be a likely option for the Greek Cypriots to sabotage EU-Turkey relations by sparking a crisis with Turkey and then inviting the EU's Rapid Reaction Force to come to their help. ${ }^{31}$ However far-fetched it might sound, this scenario would not be unlikely, given that one of the main arguments of the Greek Cypriots is that Turkey would find itself in a position to occupy a part of the EU's territory should it not withdraw its troops from the Island following the EU membership of the Island.

The EU would also face a Turkey, which would felt alienated from the EU. Such a Turkey might easily adopt anti-EU policies in the Eastern Mediterranean, Balkans, and the Middle East if its interests contradict with those of the EU. Given that trans-Atlantic bonds are also getting fragile and flimsy, Turkey siding with the United States, rather than the EU in the Eastern Mediterranean and Middle Eastern regions would not serve the interests of the EU. A further danger for the EU lies in the possibility of Turkish-Greek military confrontation. In such a case the whole enlargement process might experience a serious setback in the face of insecurity producing character of the EU-

\footnotetext{
${ }^{30}$ Wallece, 'Reconciliation in Cyprus'.

${ }^{3}$ •ibid.
} 
accession process. Moreover, if the EU as an institution does not side with Greece against Turkey, as the latest US-UK-Turkey deal over the use of NATO's assets by the European Army demonstrated, its credibility might decrease in the Greeks' eyes and this situation might constitute a negative precedent for the would-be-members.

\section{Merits of the Membership of a Loosely Centralised Federal Cyprus}

For all the interested parties to the conflict, the best possible outcome would be the accession of the Island to the EU as a whole. For this to happen, the Greek and Turkish Cypriots need to agree over the details of a constitutional arrangement, which would later be included in the EU accession treaty of the Island. Given that the two communities have well entrenched their negotiation positions for years, it might be difficult to expect a final breakthrough stemming from their own efforts. Therefore, Greece, Turkey, the United States and the European Union each should do its most to encourage them in their efforts. Of all the greatest responsibility falls on the shoulders of the European Union, since it is the only actor that can seriously affect the incentives-matrix of the communities. Both communities need to be convinced to the 'necessity' and 'legitimacy' of reaching a resolution before the accession of the Island to the EU. It is the argument of this paper that unless the EU fully supports a loosely centralised federal solution on the Island, neither of the parties would seriously engage in a negotiation process aimed at an everlasting settlement. They would continue to temporise and hope to see that the EU would cast its decision in their favour. The loosely centralised federal arrangement on the Island would be useful for a number of reasons.

First of all, this mechanism would be based on two major concessions to be given by each community. Each would have to forfeit their maximalist positions in order to reach a mutually acceptable formula. The Turkish Cypriots would not insist on the recognition of two independent states on the Island coming together under a confederal roof, for both the Greek Cypriots and the international community are sensitive over this issue. It is the view of the international community that the Island should possess a single international identity to be represented by the central government in 
Nicosia. The Turkish Cypriots need to agree to a decrease in the amount of territory they currently possess. A reduction from the current 36 percent to the 29+ percent would likely to satisfy the Greek Cypriots. The Turkish Cypriots need also agree to the gradual withdrawal of the Turkish troops from the Island as the two communities go on to experience a joint cohabitation within the European Union. However, they need to be assured that Turkey's legitimate and legal rights emanating from the 1960 agreements would be incorporated into the new treaty. ${ }^{32}$ This seems to be the only way for the Turkish Cypriots to fell themselves in safety under the rubric of the new state coming into life within the EU.

Alongside the point above, the Greek Cypriots need to give up their insistence on a unitary or tightly centralised federal state on the Island. They must stop seeing the Turkish Cypriots as a minority group but as a political community as much equal as they are. The Greek Cypriots should also concede to the reality that the Island has never been under the sole Greek rule throughout its entire history and that the proclamation of its independence in 1960 was made possible with the legal rights of Turkey being incorporated into the constitution of the new state.

Secondly, a unitary or tightly centralised political arrangement on the Island would be in contradiction with the realities of the Island. Such arrangements would hardly survive with the existing realities, As the communities have not experienced a joint life since 1963, the experience of joint governance is missing on the Island. The lack of mutual trust and cooperation is also highly evident. Emanating from the separate systems of education, religion, culture and political life, the points of divergences between the two communities are much higher than those of convergences. The lack of an interdependent economic life also fuels this communal differentiation. ${ }^{33}$

Thirdly, the establishment of a loosely centralised federal arrangement would be in accordance with the spirit of the 1960

\footnotetext{
${ }^{32}$ This should not be difficult to realise given that neither of the contracting parties to the 1960 treaties proclaimed that these are not valid any more.

${ }^{33}$ Zeliha Khashman, 'Is Federal Structure Really An Appropriate Poltical Solution for Multi-ethnic Societies?', Perceptions, Vol. 4, No. 2, 1999, pp. 85-99.
} 
treaties, which came into being upon the denial by the communities of their maximalist positions; Enosis (union of the island with Greece) and taksim (the division of the island between Turkey and Greece). The fact that the United Kingdom did not give up its sovereign rights over the Island in favour of any community, but to the joint rule of the Greek and Turkish Cypriots, neither of the communities seems to be justified to use all sovereign rights on its own and represent the international identity of the Island alone. Besides, the long-years held Turkish Cypriot position that both the proclamation of the Turkish Federated State of Cyprus in 1975 and the establishment of the Turkish Republic of Northern Cyprus in 1983 would constitute only one of the constitutive parts of the future federal state of Cyprus, should be taken as a facilitating factor.

Fourthly, Turkey would have to give its consent to the EU membership of the loosely centralised federal Cyprus, if such a solution were strongly supported by the European Union and then made a part of Turkey's accession process with the EU. Given that domestic public opinion in Turkey is much sensitive on the Cyprus dispute, any solution that preaches for the abolition of Turkey's constitutional rights over the Island, even in a gradual manner, would definitely be rejected by the majority of the Turks from the outset. ${ }^{34}$ Turkey's main interests over the Island emanate from two major consideration: One concerns the strategic location of the Island whereas the other the well-being of the Turkish Cypriot community. Since Turkey's strategic discourse is greatly affected by its relationship with Greece in the past, any solution on the Island, which might likely result in the extension of Greece's strategic influence to the region, would be adamantly resisted by the Turks. In Turkey's perception, there is no clear-cut difference between the direct rule of Greece in the Island \{Enosis) and Greek Cypriot-dominated administration, irrespective of the EU membership of the Island. In either case, the Island would come under Greece's sphere of influence. However, Turkey would not be able to resist the EU membership of the Island if the EU overtly supports its guarantorship rights and let Turkey continue its special

\footnotetext{
${ }^{34}$ Hansjorg Berg, ' Turkey and the Cyprus Question', The International Spectator, Vol. XXXIV, No. 1, 1999, pp. 111-21. See also Clement H. Dodd, ' Cyprus in Turkish Politics and Foreign Policy' in Clement H. Dodd, (ed.) Cyprus: The Need for New Perspectives, London, The Eothen Press, 1999, pp. 128-147.
} 
relationship with the Turkish Cypriots until the time it becomes an EU member itself. Moreover, Turkey does not seem to be in a morally justified position to argue against the exclusion of the Island in its entirety from the EU while it seeks membership in the same international institution.

Fifthly, by proposing a loosely centralised federal arrangement, the European Union might prove its commitment toward Turkey's EU membership, since this is the only feasible alternative that Turkey can really approve of. Regarding all other alternatives, it seems that Turkey would value its national interests over the Island more than its aspiration for EU membership, risking the rupture in its relations with the EU. After the membership of a loosely centralised Cyprus, pro-EU forces in Turkey would gain further ground and the pace of the ongoing internal transformation process would accelerate.

Sixthly, the Turkish-Greek reconciliation process would be positively affected by the solution of the Cyprus conflict. Neither Greece nor Turkey would need to spend on defence at levels more than needed. Economic resources would be released for more beneficiary sectors. The ending of the security dilemma both on the Island and in the Aegean Sea would contribute to the security of the Eastern Mediterranean region. The tarnished image of the EU as an international actor contributing to the resolution of conflicts would also be remedied.

Seventh, the loosely centralised federal Cyprus would be in accord with the ongoing integration process within the European Union. Given that today's EU can best be characterised as a political entity, which is more than a confederation but less then a federation, and that sovereignty is shared within the EU's zone among supranational organs in Brussels, national capitals and local/regional authorities, a loosely federal administrative structure would not be difficult to function on the Island. ${ }^{35}$ Both the Greek Cypriots' claim for a tightly centralised federalism and the Turkish Cypriot claim for a confederalism of two sovereign states are so much sovereigntysensitive constellations that they can find no way to survive within the

\footnotetext{
${ }^{35}$ Patrick R. Hugg, 'Cyprus Advances Towards Europe: Realism and Rationalism',
} Perceptions, Vol. 6, No. 3, 2001, pp. 92-111. 
post-sovereign institutional environment of the European Union. Even though the communities would have better life within the EU under a loosely centralised federal state, they might later turn out to have a tightly centralised administrative structure as, and if, they develop mutual trust and habits of cooperation between each other. As various EU officials have stated, the EU is ready to offer some opt-outs to the Turkish Cypriots in case they decide to join the EU alongside the Greek Cypriots. ${ }^{36}$ These derogations can be either negative, in the sense that some restrictions can be imposed on the Greek and Turkish Cypriots for the utilisation of the three fundamental rights of the European Union, or positive, in the sense that the European Union might agree to the treatment of Turkey as an EU member as far as Turkey-Cyprus relations are concerned.

\section{Conclusion}

The most important conclusion that one could draw from the above analysis is that the EU's involvement in the Cyprus dispute has not so far generated the catalytic effects as some circles expected. In the context of Cyprus, one could not see that the EU accession process served as an ideal mechanism in radiating the institutional norms of the EU's security community to conflict-riven areas around the peripheries of the continent. In fact, what happened was just the opposite.

When the Greek Cypriots have sought the EU membership mainly for security considerations vis-à-vis Turkey and the Turkish Cypriots, and when the European Union offered to Turkey the candidacy status in order to pre-empt any negative Turkish reaction to the membership of the Island to the EU before Turkey's accession, the credibility of the EU's involvement has radically eroded in Turkish

\footnotetext{
${ }^{36}$ For example, the Belgian model of federalism, which is based on the equality between the constituent parts and the central government, is recommended for Cyprus. Besides, the regulations in regard to the Aaland Islands, a Swedishspeaking Finnish territory, are put as a model before the communities of Cyprus. Regulations concerning the rights of other EU citizens to buy property in Poland, Denmark, and Malta can also constitute other role models for Cyprus. On the compatibility between the EU accession of the Island and the solution of the Cyprus dispute, see Michael Emerson and Nathalie Tocci, Cyprus As Lighthouse of the East Mediterranean, Shaping EU Accession and Re-Unification Together, Brussels, Center for Euiropean Policy Studies, 2002.
} 
eyes. This is of fundamental importance given that Turkey is the most important country in the region that has the most credible means to affect the negotiation positions of the Turkish Cypriots.

Moreover, the parties to the conflict have not grown closer to each other since the EU began to involve in the dispute quite sometime ago. When the EU's ambiguous attitude towards the ideal settlement of the dispute combined with the flawed assumptions, on which the EU's political strategies have based, the end result has become the further perpetuation of the conflict.

Based on these outcomes, this essay argued that unless the EU reversed its attitude, the risks to security and stability in the region would abound. Of which the most important one is the possibility that Turkey and the EU would face each other as contenders in the region. Therefore, the idea that the EU had better admit Cyprus as a member after the communities reached a loosely centralised federal arrangement would not only help the EU proceed with the enlargement process smoothly, but also be in harmony with the latest trend in international relations. As the decision of the Serbians and Montenegrians to create a new state (Serbia and Montenegro) out of the ashes of the former Yugoslavia has demonstrated, the establishment of loosely centralised federal entities would be the best possible answer to the question of how two adjacent communities with significant communal cleavages could/should live together, side by side, if this would certainly be the most beneficial and practical way to take. If the EU membership of the Island were added to the final agreement as a constitutive part of it, the likelihood that such a political solution would be long-lasting would abound. This seems to be the only way for the European Union to contribute to the peace and security not only on the Island, but also in the Eastern Mediterranean region. 